\title{
Realized Genetic Gains of Rust Resistant Selections of Slash Pine (Pinus elliottii var. elliottii) Planted in High Rust Hazard Sites
}

\author{
By R. Vergara ${ }^{1)}$, T. L. White ${ }^{2)}$, D. A. Huber ${ }^{3)}$ and R. A. Schmidt \\ School of Forest Resources and Conservation, Newins-Ziegler Hall, University of Florida, \\ P.O. Box 110410, Gainesville, FL 32611, USA
}

(Received $17^{\text {th }}$ May 2006)

\begin{abstract}
Summary
Realized gains from selection for resistance to the fungal disease fusiform rust caused by Cronartium quercuum f. sp. fusiforme were estimated using data from five field trials planted on large rectangular plots in high rust-hazard sites. These five realized gain trials, planted as a Best Management Practices study (BMP), compared resistant and susceptible mixtures of families from the first-generation breeding population of slash pine (Pinus elliottii var. elliottii Engelm.) in southeastern North America.

Analyses of variance (Proc Mixed using REML in SAS), conducted to test the significance of realized gains and interactions contrasting resistant with susceptible seedlots, detected important and highly significant realized gains in both rust resistance and mid-rotation yield. Significant gains were obtained for rust resistance at age 5 and stand yield at age 16 with high stability across sites and across silvicultural treatments, indicating that gains in rust resistance and the associated influence on gains in stand yield were consistent under many environmental conditions. Additionally, the values of realized gains in stand yield steadily increased with age, primarily due to increased rust associated mortality with age in the susceptible material. The $25 \%$ realized gain for rust resistant material compared to rust susceptible material obtained at age 16 was conservatively extrapolated to a 25-year-old rotation-age gain of $51.4 \mathrm{~m}^{3} \mathrm{ha}^{-1}$ (735 feet ${ }^{3}$ acre $^{-1}$ ) in inside-bark volume.
\end{abstract}

Key words: Tree improvement, forest genetics, block plots, mean annual increment, tree volume.

\section{Introduction}

Fusiform rust (Cronartium quercuum f. sp. fusiforme) is the most serious pine disease in southeastern North America (SchmidT et al., 1981; HodGE et al., 1990; SCHMIDT, 1998), and slash pine (Pinus elliottii var. elliottii Engelm.) is highly susceptible to this pathogen. Fusiform rust causes stem galls that decrease product values and cause growth reduction, deformations, and mortality which produce significant losses in stand yield (SOHN and GoDDARD, 1979; SCHMIDT et al., 1981; WEBB and Patterson, 1984; Schmidt, 1998; Brawner et al., 1999). Those yield losses account for hundreds of millions of dollars in economic costs across southeastern

\footnotetext{
1) Present address: Laboratory of Molecular Systematics, FLMNH, Dickinson Hall, University of Florida, P.O. Box 117800, Gainesville, FL 32611, USA. Email: rodver@ufl.edu

2) Email: tlwhite@ufl.edu

3) Email: dahuber@ufl.edu
}

North America (Phelps and Chellman, 1975; ANDERson et al., 1986; CuBbaGe et al., 2000).

The increase in disease incidence and area seriously affected by fusiform rust in southeastern North America since 1930 (PhElPS and Chellman, 1975; GRIGGS and SCHMIDT, 1977) was caused by factors related to increased management intensity (SCHMIDT, 1998). Reduction of wildfires, coupled with more abundant and dense young plantations, resulted in a historical annual rust increment of 2-3\%. More recently, fertilization and weed control have exacerbated the problem, because unlike some pathogens, rust infection increases in rapidly-growing trees (ScHMidT et al., 1981; PYE et al., 1997; BRAWNER, 1998; SCHMIDT, 1998).

Many efforts have been aimed at controlling rust incidence in plantations, but the most effective and economically-viable tool for managing rust epidemics and reducing damage is selection, breeding, and planting of genetically-resistant material (PYE et al., 1997; SCHMIDT, 1998; WALKInshaW, 1999; CUBBAGE et al., 2000). Selection in high-rust-hazard sites, testing, and breeding have produced substantial rust resistance in some families of slash pine (HoDGE et al., 1990; WHITE et al., 1993; BRAWNER et al., 1999). Commercial production of rustresistant seedlings began around 1980 and by 1997, almost half of the planted seedlings of slash pine contained increased resistance to fusiform rust (PyE et al., 1997).

The assessment of realized gains is important to justify the investment in genetic improvement (ZOBEL and TALBERT, 1984; ElDRIDGE et al., 1994), and the evaluation of the impact of rust resistance on stand yield is important to quantify those realized gains. Differential rust resistance among slash pine families and seedlots has been demonstrated using row-plots. A study assessing rust incidence in three-tree row plots from an intensely-selected population, at three and five years after planting, found significant realized gain above unimproved controls (SOHN and GODDARD, 1979). I/U ratios (total rust incidence in the improved material divided by total rust incidence in the unimproved control) ranged from 0.50 to 0.77 depending on rust hazard (defined as total percentage rust incidence on unimproved material).

Additionally, a study using material from seed production areas and a seed orchard created from selections made in heavily rust infected stands evaluated in 17 row-plot progeny tests showed significant gain in rust resistance at all rust hazard levels (HoDGE et al., 1990). 
The seed production areas and seed orchard material had $I / U$ ratios of 0.67 and 0.80 , respectively. The evaluations made at ages between 3 and 10 years showed relatively constant $I / U$ ratios across rust hazard levels indicating little genotype-by-environment interaction. Another study corroborating the low interaction across sites tested improved versus unimproved families in row-plots on 11 sites (LOPEZ-UPTON et al., 2000). The $I / U$ ratios obtained ranged from 0.35 to 0.80 , and the adjusted model between improved and unimproved material was highly significant with a slope ( $I / U$ ratio) of 0.71 and $\mathrm{R}^{2}=0.91$.

A broader study conducted by DHAKAL et al. (1996) evaluated realized genetic gains for rust resistance using 175 control-pollinated tests with 2051 first-generation families arranged in row and single-tree plots. The $I / U$ ratios ranged from 0.53 to 1.37 depending of the level of improvement in the families. For example, seedlots representing unrogued and rogued seed orchards had 1.24 and $0.81 I / U$ ratios, respectively.

To date, most evaluations of rust resistance in slash and loblolly pine (Pinus taeda L.) have estimated differences in rust incidence between families or seedlots (SOHN and GodDARD, 1979; HodGe et al., 1990; DHAKAL et al., 1996; LopEz-UPTON et al., 2000). It is clear that tree improvement programs have successfully produced material that incurs less disease on a wide range of sites. However, these studies have not generally quantified the effect of rust resistance on growth and stand yield. To provide an unbiased estimate for the effect of rust resistance on per unit area volume yield requires experiments planted in large rectangular plots (WHITE, 1987; Foster, 1992; LAMBETH et al., 1994). Rust-associated mortality on high-rust-hazard sites (ANDERSON et al., 1986) can alter competition patterns in row-plot trials, thereby magnifying the competitive advantages of resistant families growing near susceptible families. Large rectangular plots avoid this problem since they allow each seedlot to express its genetic potential without interference from other seedlots (ZOBEL and TALBERT, 1984; LowerTs, 1986; Williams and MATHESON, 1994). However, large plots have low statistical precision and a large number of sites is needed to precisely estimate the magnitude of genetic differences (DHAKAL et al., 1996).

The effects of rust resistance on slash pine growth and stand yield have been evaluated extensively in only one large rectangular-plot study installed between 1985 and 1987 (HodGe et al., 1993). This Best Management Practices (BMP) study has been measured and analyzed at different ages from five years after planting (HoDGE et al., 1993; SCHMIDT and ALLEN, 1997) to mid-rotation age (12-year) (BRAWNER, 1998; BRAWNER et al., 1999), finding significant gains in rust resistance (average $R R / R S=0.37$, where $R R$ represents a selected rustresistant seedlot and $R S$ represents a rust-susceptible seedlot worse than unimproved material) and stand yield (17\% at age 12 and a projected gain of 25 and $33 \%$ at ages 20 and 25 , respectively).

The present study contains new information from the BMP experiment, using 5, 12, and 16-year data to assess the impact of slash pine rust resistance on growth and stand yield. The original BMP study was installed with slash and loblolly pine on eight sites across high-rust-hazard environments in the southeastern USA (SchmidT and ALLEN, 1997). The present study evaluated slash pine on the five available trials for the species planted in high rust hazard locations.

The objectives of this study were to: (1) evaluate the effect of rust-resistance in slash pine on growth and stand yield at mid-rotation using large rectangular plots; (2) estimate and compare the effects of rust resistance on growth and stand yield across ages; and (3) assess the impact of silviculture and rust hazard on the effect of rust resistance for growth and stand yield.

\section{Materials and Methods}

\section{Breeding Population and Genetic Trials}

The plant material in the BMP study consists of selections from a first-generation breeding population of slash pine (Pinus elliottii var. elliottii Engelm.) in southeastern North America. The five companion trials analyzed is this study were planted by the Integrated Forest Pest Management Cooperative on high-rust-hazard sites located in north Florida and south Georgia between 1985 and 1987 (SCHMIDT et al., 1995) (Figure 1, Table 1).

These trials compare rust-resistant $(R R)$ with rustsusceptible $(R S)$ seedlots. $R R$ and $R S$ are bulk-mixes of six rust-resistant and six rust-susceptible wind-pollinated families, respectively. The predicted rust resistance of the six families included in each seedlot was obtained from the predicted breeding values for rust resistance, designated as R50 values (WHITE et al., 1996). R50 values indicate the percentage of total rust incidence expected for a particular seedlot, when unimproved material would incur $50 \%$ rust in the same environment (HoDGE et al., 1989). Best linear prediction (BLP) (White and Hodge, 1988) was used to predict breeding values for approximately 2500 first-generation parents

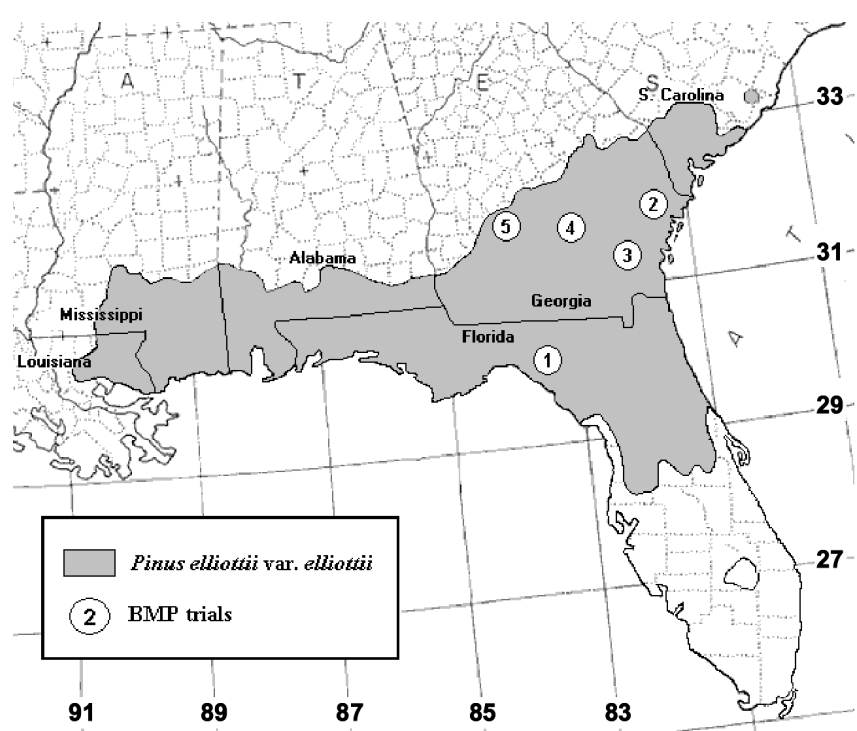

Figure 1. - Natural range of slash pine (CRITCHFIELD and LitTLE, 1966) and location of the five BMP trials used in the analysis. 
Table 1. - Best Management Practices (BMP) trials used in the analysis.

\begin{tabular}{|c|c|c|c|c|c|c|c|c|c|}
\hline \# & Trial & $\begin{array}{c}\text { County, } \\
\text { State (place) }\end{array}$ & $\begin{array}{c}\text { Rust } \\
\text { hazard }^{1}\end{array}$ & $\begin{array}{l}\text { Site } \\
\text { index } \\
(\mathbf{m})^{2}\end{array}$ & $\begin{array}{c}\text { Date } \\
\text { planted }\end{array}$ & $\begin{array}{l}\text { Measure } \\
\text { ages }\end{array}$ & $\underset{\#^{3}}{\operatorname{Rep}}$ & $\begin{array}{c}\text { No. of } \\
\text { seedlots }\end{array}$ & $\begin{array}{c}\text { Density } \\
\text { (tree/ha) }\end{array}$ \\
\hline 1 & 551 & $\begin{array}{l}\text { Taylor, FL } \\
\text { (Perry) }\end{array}$ & $28.3 \%$ & 22.5 & 1985 & $5,12,17$ & 3 & 2 & 1796 \\
\hline 2 & 552 & $\begin{array}{l}\text { Bulloch, GA } \\
\text { (Statesboro) }\end{array}$ & $63.7 \%$ & 23.8 & 1986 & $5,12,16$ & 3 & 2 & 1796 \\
\hline 3 & 553 & $\begin{array}{l}\text { Wayne, GA } \\
\text { (Screven) }\end{array}$ & $41.8 \%$ & 22.2 & 1986 & $5,12,16$ & 3 & 2 & 1495 \\
\hline 4 & 554 & $\begin{array}{l}\text { Wheeler, GA } \\
\text { (Mc Rae) }\end{array}$ & $44.1 \%$ & 23.1 & 1986 & $5,12,16$ & 3 & 2 & 1796 \\
\hline 5 & 555 & $\begin{array}{l}\text { Sumter, GA } \\
\text { (Americus) }\end{array}$ & $36.3 \%$ & 20.1 & 1987 & $5,12,15$ & 3 & 2 & 1796 \\
\hline \multicolumn{10}{|c|}{$\begin{array}{l}\text { 1) Realized total rust incidence at age five averaging rust-resistant }(R R) \text { and rust-sus- } \\
\text { ceptible }(R S) \text { seedlots with the formula }(((R R+R S) / 2)+R S) / 2 \text { in order to represent } \\
\text { an unimproved seedlot (i.e. } \mathrm{R} 50=50) \text {. }\end{array}$} \\
\hline \multicolumn{10}{|c|}{$\begin{array}{l}\text { 2) Site index on a 25-year basis (PIENAAR et al., 1990) estimated at age } 16 \text { and based on } \\
R R \text { performance in the trial. }\end{array}$} \\
\hline
\end{tabular}

in 1995 (WhITE et al., 1996). The R50 averages for the six parents producing the offspring of the $R R$ and $R S$ seedlots were $17.8 \%$ and $68.8 \%$, respectively ${ }^{4}$. Because the seeds were harvested from wind-pollinated seed orchards, an R50 of $45 \%$ is assumed for pollen contribution (HoDGE et al., 1993). Therefore, the mean predicted $\mathrm{R} 50 \mathrm{~s}$ for the $R R$ and $R S$ seedlots are $31 \%$ $(17.8 * 0.5+45 * 0.5)$ and $57 \%(68.8 * 0.5+45 * 0.5)$, respectively. These seedlots have approximately the same mean predicted gains in growth rate based on their BLP values for volume (WHITE et al., 1996). Predicted parental breeding values in growth rate for the six parents in $R R$ and in $R S$ averaged $19.5 \%$ and $14.4 \%$ above unimproved material, respectively (VERGARA, 2003; Table A-4). Considering a pollen contribution with a predicted gain in growth rate of $7 \%$ (considering $30 \%$ pollen contamination, FRIEDMAN and ADAMS, 1985; ELKASSABY et al., 1989), the mean predicted gains in growth rate for the $R R$ and $R S$ seedlots are $13 \%$ $(19.5 * 0.5+7 * 0.5)$ and $11 \%(14.4 * 0.5+7 * 0.5)$, respectively.

\section{Experimental Design and Data Organization}

The original BMP study was installed to assess the effect on rust resistance of eight sites, two oak treatments (presence or absence), two species (slash and loblolly pine), two seedlots ( $R R$ and $R S$ ), three cultural treatments, and three replications (SCHMIDT and ALLEN, 1997). However, the information utilized in this study (Table 1) included only five sites due to low survival or absence of slash pine on three of the original sites, one species, and two of the three cultural treatment. Therefore, the final experimental design at each of the five sites was a $2 \times 2 \times 2 \times 3$ randomized complete block splitplot design with two oak treatments, two seedlots, two cultural treatments, and three replications nested within oak treatment (Figure 2).

Before site preparation at each site, two areas of approximately 25 ha were located to apply the oak treat-

4) The individual breeding values can be found in VerGaRA (2003, Table A-4). ments. All oaks were removed in the "oak-free" area, and the "oak-present" area as a control. Within each area, three replications of whole-plots with two seedlots ( $R R$ and $R S$ ) were randomly located. Finally, within each whole-plot, three cultural treatments were randomly assigned as sub-plots. The two cultural treatments included in this paper were "growth", consisting of fertilization and herbicide applied in the planting year only, and "control", without treatment.

In 2001, a total of 120 rectangular plots and nearly 4,000 trees were measured in five trials. Each gross plot had 0.1 ha with approximately 180 planted trees having between two and four buffer rows planted with non-

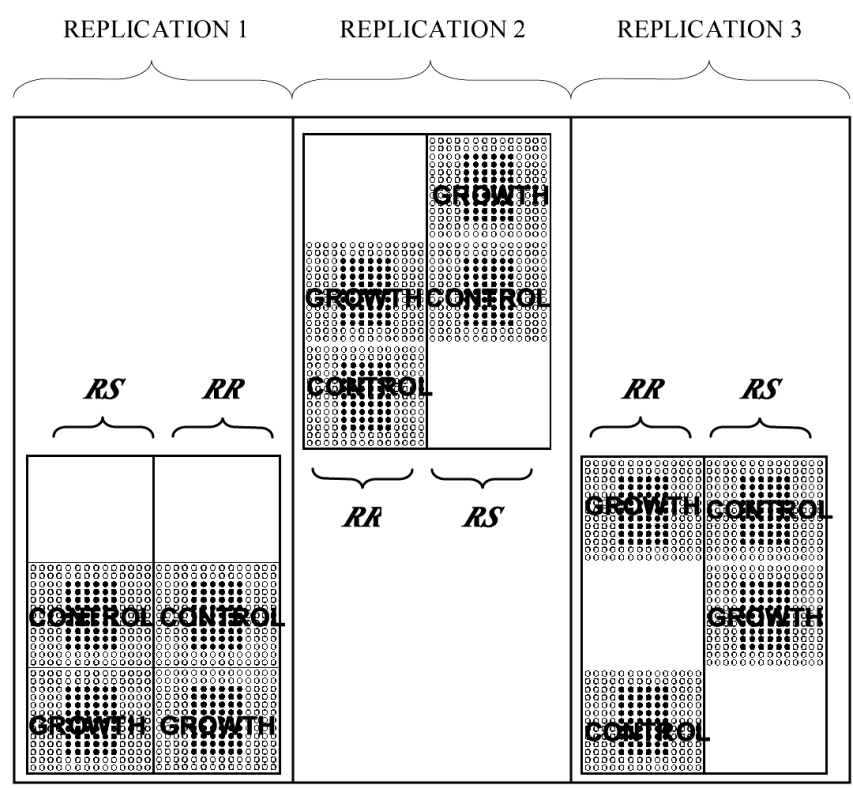

Figure 2. - BMP study experimental design. Example of an oak-treatment area with three replications, two seedlots as whole-plot (rust-resistant $=R R$ and rust-susceptible $=R S$ ), and two cultural treatments as sub-plot (Growth = fertilizer and herbicide in year 1 . Control = no treatment). Blank areas in the drawing represent the cultural treatment and loblolly pine plots excluded. - inner measure trees. $\mathbf{O}=$ outer trees (buffer). Only the inner trees were measured. 
measure trees (Figure 2). Only trees in the inner area of plots were measured, and these areas averaged 33 trees per plot at age 16. Trees were measured in each trial at five, 12 and 16 (15-17) years from planting (Table 1).

Variables measured were dbh (stem diameter outside bark at $1.4 \mathrm{~m}$ ), total height, and branch or stem galls ( 0 = healthy, $1=$ only branch galls, or $2=$ at least one stem gall) for each measure tree. Inside bark volume (bole) (FANG et al., 1999) and height-dbh ratio were calculated for each tree. The individual tree information was summarized on a per unit area basis obtaining one record per plot (experimental unit) for the following variables: percentage survival obtained as the fraction of planted trees (SURV), percentage total rust incidence (including trees with galls on branches or stem) (RUST), percentage stem rust incidence (including trees with at least one stem gall) (STEM), site index on a 25-year basis estimated using the anamorphic site index equation of PIENAAR et al. (1990) (SI25) (m) representing the seedlot's dominant height, average height-dbh ratio of living trees in the plot (HDR) $\left(\mathrm{m} \mathrm{cm}^{-1}\right)$, average volume of living trees in the plot (TREEVOL) $\left(\mathrm{m}^{3}\right)$, and mean annual increment (MAI) $\left(\mathrm{m}^{3} \mathrm{ha}^{-1}\right.$ year $\left.^{-1}\right)$ which represents stand yield. To employ the site index equation, dominant height was defined as the average height of the largest half of the trees in the plot based on dbh (pers. comm. Dr. BARRY SHIVER, modified from BAILEY and BRoOKs (1994)).

Site indices were estimated using last-measured heights of the $R R$ seedlot only, as the BMP study does not have a conventional unimproved control, i.e. the $R S$ seedlot is disease susceptible. Therefore, site indices may be slightly overestimated, because the volume breeding value for $R R$ is approximately $13 \%$ above seedlots that are unimproved for volume. Rust hazard in each trial was estimated using total rust incidence at age five (DHAKAL et al., 1996) with the formula $(((R R+R S) / 2)+R S) / 2$ in order to obtain an estimation nearer than expected for unimproved material. This is because the mean predicted $R 50 \mathrm{~s}$ for $R R=31 \%$, $R S=57 \%$, and $(((31+57) / 2)+57) / 2$ is approximately $50 \%$. The values of site index and rust hazard obtained in each trial are shown in Table 1.

\section{Data Analysis}

\section{Site-by-site analysis}

Evaluation of seedlot effects and the interaction of seedlot effects with other treatments on tree performance was conducted by analysis of variance (ANOVA) on each site at each measurement age utilizing restricted maximum likelihood analysis (REML) in Proc Mixed (SAS, 1996). Plot means or totals for each variable were used as the unit of observation. In the analyses, replications were treated as random effects, while oak treatments, seedlots, and cultural treatments were treated as fixed effects. Before analysis in Proc Mixed, a full linear model was run in Proc GLM (SAS, 1990) in order to locate non-significant interaction effects using Satterthwaite approximate $F$ tests (SATTERTHWAITE, 1946). Nonsignificant terms were dropped from the model using the sometimes-pooling technique when p-values were greater than 0.25 (BozIvich et al., 1956), to increase the power of the tests of significance. Finally, a reduced model was run for each variable at each age. The full model used in Proc GLM was:

$$
\begin{aligned}
y_{\mathrm{ijkl}}= & \mu+\tau_{\mathrm{i}}+\beta_{\mathrm{j}(\mathrm{i})}+\gamma_{\mathrm{k}}+(\tau \gamma)_{\mathrm{ik}}+(\gamma \beta)_{\mathrm{kj}(\mathrm{i})}+\varphi_{\mathrm{l}}+(\tau \varphi)_{\mathrm{il}}+ \\
& (\gamma \varphi)_{\mathrm{kl}}+(\tau \gamma \varphi)_{\mathrm{ikl}}+\epsilon_{\mathrm{ijkl}}
\end{aligned}
$$

where

$y_{\mathrm{ijkl}}=$ RUST, STEM, SI25, HDR, TREEVOL or MAI for the $\mathrm{i}^{\text {th }}$ oak treatment in the $\mathrm{j}^{\text {th }}$ replication within the $i^{\text {th }}$ oak treatment, $\mathrm{k}^{\text {th }}$ seedlot, and $\mathrm{l}^{\text {th }}$ cultural treatment,

$\mu \quad=$ Overall mean,

$\tau_{i} \quad=$ Fixed effect of the $i^{\text {th }}$ oak treatment $(i=$ oakfree or oak-present),

$\beta_{\mathrm{j}(\mathrm{i})}=$ Random effect of the $\mathrm{j}^{\text {th }}$ replication nested within the $i^{\text {th }}$ oak treatment $(j=1,2$ or 3 in each oak treatment),

$\gamma_{\mathrm{k}} \quad=$ Fixed effect of the $\mathrm{kth}$ seedlot $(\mathrm{k}=R R$ or $R S)$,

$(\tau \gamma)_{\mathrm{ik}}=$ Fixed effect of the interaction of oak treatment and seedlot,

$(\gamma \beta)_{\mathrm{kj}(\mathrm{i})}=$ Random whole-plot error which is the seedlot by replication within oak treatment interaction,

$\varphi_{1} \quad=$ Fixed effect of the lth cultural treatment (l= control or growth),

$(\tau \varphi)_{\text {il }}=$ Fixed effect of the interaction of oak treatment and culture,

$(\gamma \varphi)_{\mathrm{kl}}=$ Fixed effect of the interaction of seedlot and culture,

$(\tau \gamma \varphi)_{\mathrm{ikl}}=$ Fixed effect of the interaction of oak treatment, seedlot and culture, and

$\epsilon_{\mathrm{ijkl}} \quad=$ Random sub-plot error.

In the model, total rust incidence (RUST), stem rust incidence (STEM), and height-dbh ratio (HDR) were analyzed without transformation, because evidence shows that REML estimates are robust to violations of normality (BANKS et al., 1985; WESTFALL, 1987).

Using least square means (lsmeans), realized gains were calculated for each variable at each site and age. Significance of $R R$ 's genetic superiority was obtained looking at the seedlot effects in the ANOVA. The $R R$ 's genetic superiority (realized gain) for SI25, HDR, TREEVOL and MAI was estimated comparing the $R R$ 's seedlot performance against $R S$, with the formula Gain\% $=((R R-R S) / R S) * 100$, where Gain\% is the percentage of realized gain. Rust resistance realized gains were calculated as a measure of seedlot incidence adjusted to the rust hazard level in each site as follows. Total rust incidence per plot (RUST) and stem rust incidence per plot (STEM) were transformed to adjusted incidence (I50 and S50, respectively) using the hypothesis of proportional resistance (HoDGE et al., 1993). The transformation of STEM to S50 was made supposing that the hypothesis of proportional resistance to total rust incidence applies to stem rust incidence as well, which has not been documented. Consequently, results related to $\mathrm{S} 50$ must be taken with caution. The formulas used were $\mathrm{I} 50=\left(\mathrm{RUST}^{*} 50\right) /($ rust hazard $)$ and $\mathrm{S} 50=$ $\left(\mathrm{STEM}^{*} 50\right) /($ rust hazard) at each age, where rust hazard is defined as the observed total rust incidence on $R R$ and $R S$ seedlots combined by the formula 
1956) were dropped from the full model and a final reduced model was run for each variable at each age. Realized gains and significance of $R R$ 's genetic superiority were estimated in the same way as for the site-bysite analysis.

\section{Age-seedlot interactions}

To compare gains assessed at different trial ages, age was added as a repeated measures factor in the acrosssites linear model, testing age $\mathrm{x}$ seedlot interactions following the methodology of BozIVICH et al. (1956) in order to drop non-significant interactions (VERGARA, 2003). Significant age $\mathrm{x}$ seedlot interactions were plotted to examine biological meaning in each trial.

\section{Results and Discussion}

\section{Realized Gains in Rust Incidence}

To evaluate rust incidence on the two seedlots $R R$ and $R S$, data from five-year-old measurements were used, because at early ages some of the rust incidence is not evident and after age five, the effect of mortality can bias rust incidence estimations (PHELPS and CHELLMAN, 1975; ANDERSON et al., 1986; SCHMIDT and AlLEN, 1997). Realized gains in rust resistance at five years have already been evaluated in the BMP study by HoDGE et al. (1993), SCHMIDT and ALLEN (1997) and BRAWNER (1998). However, the current evaluation used only a portion of the same data and a different methodology in the analysis.

\section{Individual site analysis}

The differences in RUST and STEM between $R R$ and $R S$ were highly significant $(\alpha=0.01)$ at all sites. In all sites, $R R$ had consistently lower rust incidence than $R S$ (Table $2 a$ and $b$ ). In addition, consistency in $R R$ superiority was found in every combination of silvicultural treatments in all sites. Moreover, significant interactions between seedlot and silvicultural treatments were not found at any site ( $\alpha=0.1$ level, data not shown). This absence of interactions denotes a high stability of genetic resistance in rust-resistant seedlots across silvicultural treatments.

The expression of genetic resistance is given by I50 and S50 values (realized percentage of total rust incidence and stem rust incidence, respectively, of the $R R$ seedlot, when rust hazard is $50 \%$ as estimated by $(((R R+R S) / 2)+R S) / 2)$. The average realized I50s by site at age five ranged between 17.9 and $24.9 \%$ (Table $2 a$ ), and the individual values for each site/oak/culture combination ranged between 7.2 and $30.0 \%$. Average realized S50s by site at age five ranged between 7.1 and $13.7 \%$ (Table $2 b$ ), and values among treatment combinations ranged between 3.6 and $22.3 \%$. Therefore, we would expect a maximum total rust incidence of $30 \%$ and a maximum stem rust incidence of $22 \%$ when planting this rust-resistant material on $50 \%$ rust hazard sites, i.e. sites where unimproved material have $50 \%$ total rust incidence.

Impact of site, silviculture and age on realized gains for RUST and STEM

Across-site analysis at each age. An across-site analysis allowing for heterogeneous variances by site was conducted for each variable at each age to confirm tendencies found in the site-by-site analysis and to test for interactions across sites (Table 3). The results at five years for RUST and STEM (Figure $3 a$ and $b$ ) confirmed

Table 3. - P-values obtained in the REML-Proc Mixed (SAS 1996) run for the BMP study across sites fitting separate error variances at each site. For random effects the $p$-values were obtained from asymptotic $t$ tests. Only effects with a pvalue of 0.25 or less for at least one response variable are shown.

\begin{tabular}{|c|c|c|c|c|c|c|c|c|c|}
\hline Source & Effect & Df & Age & RUST & STEM & SI25 & HDR & $\begin{array}{l}\text { TREE } \\
\text { VOL }\end{array}$ & MAI \\
\hline \multirow{3}{*}{ Seedlot } & \multirow{3}{*}{ Fixed } & \multirow{3}{*}{1} & 5 & $<.001^{* *}$ & $0.001^{* *}$ & 0.346 & 0.203 & 0.974 & 0.320 \\
\hline & & & 12 & $<.001^{* *}$ & $0.002^{* *}$ & 0.956 & $<.001^{* *}$ & 0.728 & 0.133 \\
\hline & & & 16 & $<.001^{* *}$ & $0.001^{* *}$ & $0.003^{* *}$ & $<.001^{* *}$ & 0.348 & $0.003^{* *}$ \\
\hline \multirow{3}{*}{ Seedlot $\mathrm{x}$ site } & \multirow{3}{*}{ Random } & \multirow{3}{*}{4} & 5 & $D$ & 0.205 & $D$ & $D$ & $D$ & $D$ \\
\hline & & & 12 & 0.110 & $0.095^{+}$ & 0.999 & $D$ & $D$ & 0.180 \\
\hline & & & 16 & 0.999 & 0.150 & $D$ & $D$ & $D$ & 0.999 \\
\hline \multirow{3}{*}{ Seedlot $\mathrm{x}$ site $\mathrm{x}$ oak } & \multirow{3}{*}{ Random } & \multirow{3}{*}{4} & 5 & $D$ & $D$ & $D$ & $D$ & $D$ & $D$ \\
\hline & & & 12 & $D$ & $D$ & 0.110 & $D$ & $D$ & $D$ \\
\hline & & & 16 & 0.170 & $D$ & $D$ & $D$ & $D$ & 0.130 \\
\hline \multirow{3}{*}{ Seedlot $x$ culture } & \multirow{3}{*}{ Fixed } & \multirow{3}{*}{1} & 5 & $D$ & $0.051^{+}$ & $D$ & $D$ & $D$ & $D$ \\
\hline & & & 12 & $0.023^{*}$ & 0.146 & $D$ & $D$ & $D$ & $D$ \\
\hline & & & 16 & $D$ & $0.062^{+}$ & 0.278 & $D$ & $D$ & $D$ \\
\hline
\end{tabular}

Variables. RUST $=$ total rust incidence $(\%)$, STEM $=$ stem rust incidence $(\%)$, SI25 = site index on a 25-year basis (m) (PIENAAR et al., 1990) representing the seedlot's dominant height, HDR = average height-dbh ratio of living trees in the plot $\left(\mathrm{m} \mathrm{cm}^{-1}\right)$, TREEVOL $=$ average volume of living trees in the plot $\left(\mathrm{m}^{3}\right)$, MAI = mean annual increment $\left(\mathrm{m}^{3} \mathrm{ha}^{-1}\right.$ year $\left.{ }^{-1}\right)$ representing stand yield.

Factors. seedlot (rust-resistant mixture and rust-susceptible mixture), site (tests growing on five different environments), oak (oak-free and oak-present), culture (growth = fertilizer plus herbicide and control = no culture).

$D=$ Non-significant interaction dropped in the model with $p>0.25$ (BozIVICH et al., 1956). In the cases when the three factor interaction had a $p<0.25$, the interaction seedlot $\mathrm{x}$ site was never dropped. Significance levels: ${ }^{+} \alpha=0.1,{ }^{*} \alpha=0.05, * * \alpha=0.01$. 
that the difference in rust resistance between $R R$ and $R S$ was highly significant at $\alpha=0.01$ with realized values $\mathrm{I} 50=21.9 \%$ and $\mathrm{S} 50=11.2 \%$, corroborating the result obtained when the same study was analyzed by Hodge et al. (1993), Schmidt and Allen (1997), and BRAWNER (1998).

Consistent superiority of rust-resistant material over unimproved seedlots has been reported in virtually every study for slash pine. Realized $\mathrm{I}_{50 \mathrm{~s}^{5}}$ of $25-39 \%$ (SoHN and GODDARD, 1979), 34-40\% (HodGe et al., 1990), 26-35\% (DHAKAL et al., 1996), 18-40\% (LOPEZUPTON et al., 2000), and $22 \%$ from this study demon-

5) Values were transformed in I50s in order to compare them with our results. By definition $\mathrm{I} 50=50(\mathrm{Ri} / \mathrm{Ru})$, where $\mathrm{Ri}=$ rust incidence in improved seedlots and $\mathrm{Ru}=$ rust incidence in unimproved seedlots).
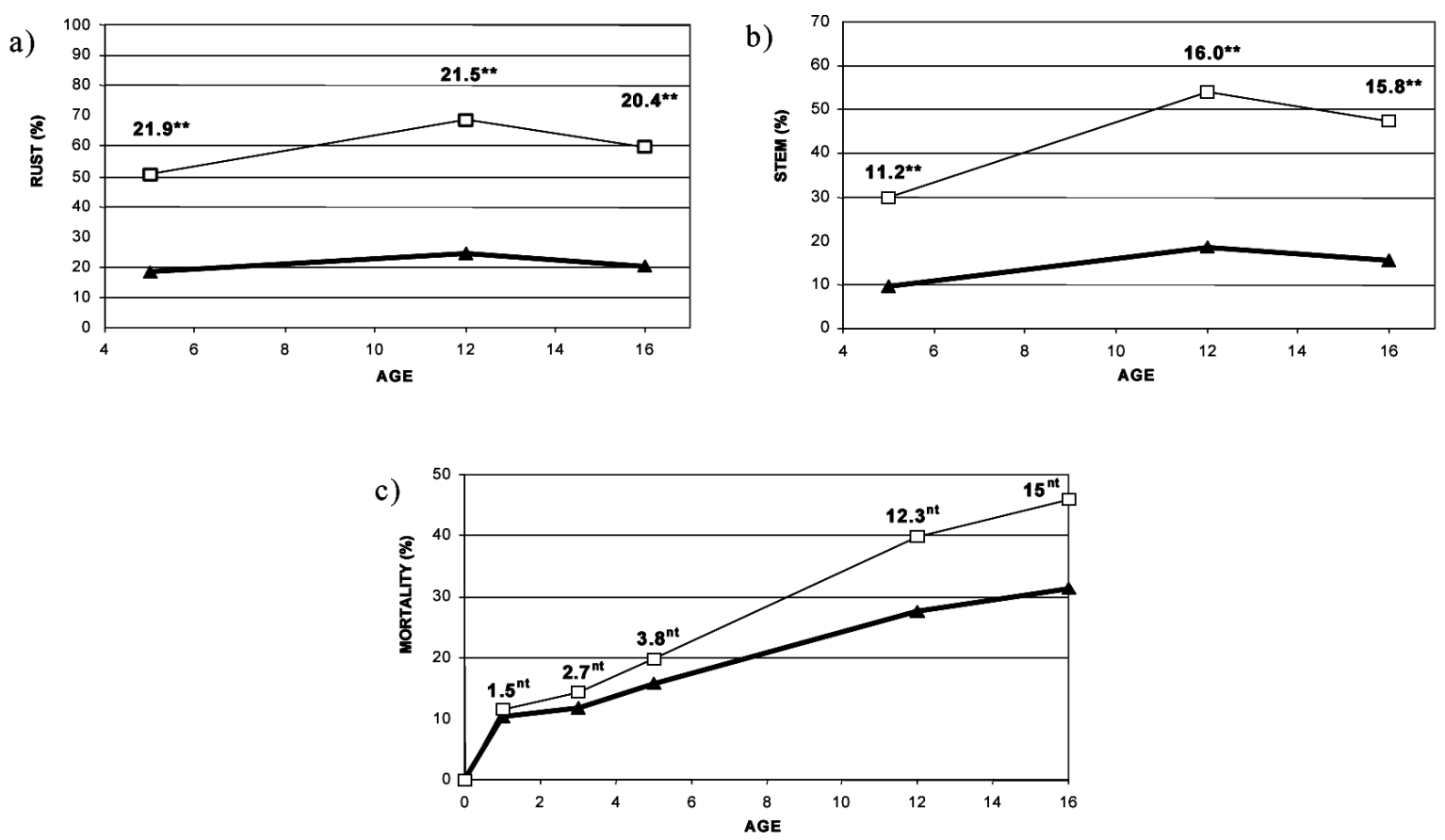

d)
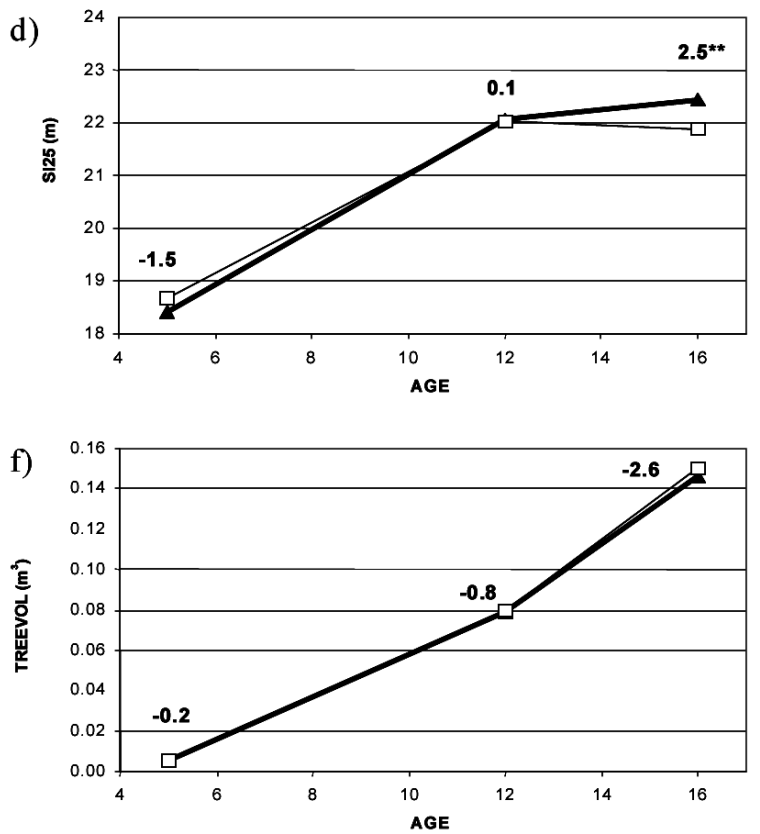
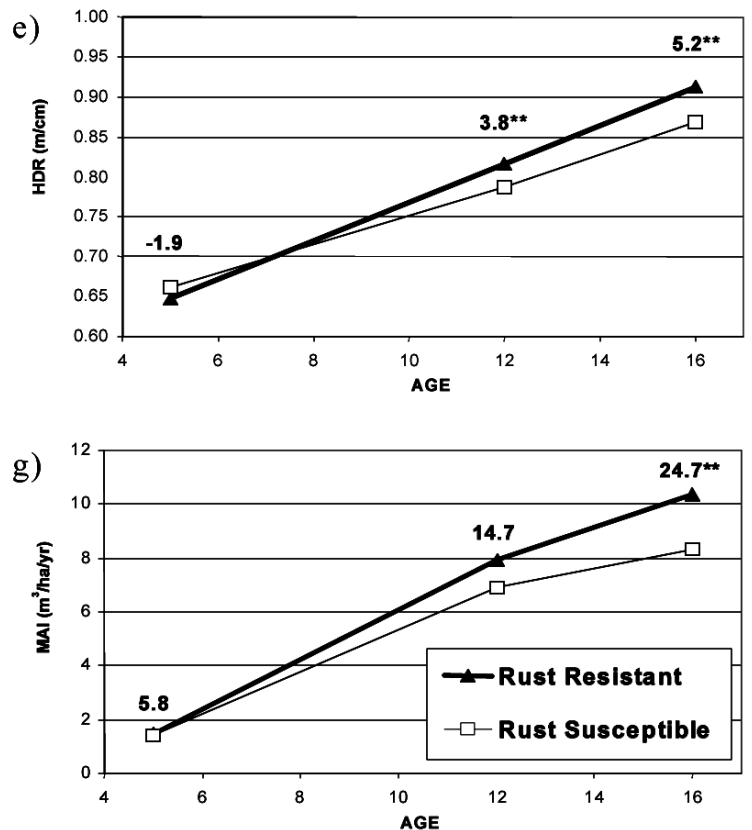

Figure 3. - Least square means from across-site analyses at ages five, 12 and 16 years old. Rust-resistant mixture $(R R)$ and rust-susceptible mixture $(R S)$ average performance for a) RUST = total rust incidence (\%), b) STEM = stem rust incidence (\%), c) Mortality (\%), d) SI25 = site index on a 25-year basis (m) (PIENAAR et al., 1990), representing the seedlot's dominant height. e) HDR = average height-dbh ratio of living trees in the plot $\left(\mathrm{m} \mathrm{cm}^{-1}\right)$, f) TREEVOL = average volume of living trees in the plot $\left(\mathrm{m}^{3}\right)$, g) MAI = mean annual increment $\left(\mathrm{m}^{3} \mathrm{ha}^{-1} \mathrm{year}^{-1}\right)$ representing stand yield. The values above the lines are I50s (realized total rust incidence on $R R$ when rust hazard is $50 \%$ ) in a, S50s (realized stem rust incidence on $R R$ when rust hazard is $50 \%)$ in b, differences in mortality $(R S$ $R R$ ) in c, and realized gains $\left(\right.$ Gain\% $\left.=((R R-R S) / R S)^{*} 100\right)$ in $\mathrm{d}$, e, f, and g. Significance levels in gain: ${ }^{+} \alpha=0.1$, $*_{\alpha}=0.05,{ }^{*} \alpha=0.01,{ }^{\mathrm{nt}}=$ not tested. 
strated the highly significant gain for first-generation selections. Thus, depending on the genetic quality of the seedlots planted, resistant material incurred 20-40\% total rust incidence on sites in which unimproved material is $50 \%$.

The stability of rust resistance across sites was evidenced by consistently non-significant seedlot $\mathrm{x}$ site interactions for RUST and STEM at all ages (Table 3). In one case, a weak interaction for STEM was significant at 12 years old, but not at five years old. Additionally, the three way interactions of seedlot $\mathrm{x}$ site $\mathrm{x}$ silvicultural effects were non-significant at $\alpha=0.1$ (Table 3 ). Similar to site effects, interactions of seedlots with silvicultural treatments were tested in the across-site analysis to assess the impact of oak removal and culture on rust resistance responses. In general, neither oak treatment nor culture had a significant impact on the realized gains obtained. Seedlot $x$ culture was the only significant interaction for RUST at 12 years old and significant for STEM at five and 16 years old (Table 3). However, the graphic analysis of these significant interactions (VERGARA, 2003; Figure 3-4) did not show a change in the general tendencies, where rust susceptible seedlots were always more successfully attacked by fusiform rust than rust resistant seedlots. These results are consistent with those from other studies in slash pine indicating that rust-resistant seedlot mixtures are consistently resistant across sites (SCHMIDT and GODDARD, 1971; GODDARD and SCHMIDT, 1979; HodGE et al., 1990; DHAKAL et al., 1996) and silvicultural treatments (LOPEZ-Upton et al., 1999; LOPEZ-UPTON et al., 2000). Nevertheless, this tendency is not always true when analyzing single families. In that case, family $\mathrm{x}$ environment interactions, especially in low-rust-hazard sites, can be significant with rank changes in slash pine (KuHlman et al., 1995; DiETERs et al., 1996; SCHMIDT et al., 1999) and in loblolly pine (McKEAND et al., 2003).

There were substantial and consistent gains in rust resistance, and the magnitude of these gains should be directly predictable from the best linear prediction (BLP) breeding values (mean predicted R50s). Correspondingly, the overall realized rust resistance (I50) should be close to the mean predicted R50s for $R R$ calculated by WHITE et al. (1996). However, the mean predicted BLP breeding value for the $R R$ seedlot, $\mathrm{R} 50=31.4 \%$, was larger than the realized $\mathrm{I} 50=21.9 \%$ in this study. This implies that the BLP-predicted breeding values under-predicted the true rust-resistance of the $R R$ seedlot. Curiously, in the validation done by Hodge et al. (1993) in the same study that used the previous 1988 BLP breeding values (R50s, HoDGE et al., 1989), overall realized rust resistance agreed very well with the mean predicted value $(\mathrm{I} 50=25.3 \%$ vs $\mathrm{R} 50=23.7 \%)$. The most plausible explanation for the lack of agreement of predicted and observed realized gains in this study is an altered assumption regarding additive genetic variance in the 1995 BLP analysis. In 1995, the assumption of variance among open-pollinated families was modified from the traditional one-fourth of the additive variance to one-third of the additive variance (WHITE et al., 1996) reducing the spread of predictions. Therefore, with the 1995 BLP predictions, the mean predicted R50 value of
$R R$ was higher than with the 1988 predictions. Following the approach of DHAKAL (1995), the mean prediction of rust resistance for the $R R$ seedlot would be $\mathrm{R} 50=23.25 \%$ using the previous assumption of onefourth, which is much closer to the realized I $50=21.9 \%$.

Age-seedlot interactions. In order to compare realized I50s and S50s assessed at three trial ages, an across-site analysis was performed using age as a repeated measure. In that analysis, a highly significant $(\alpha=0.01)$ influence of age on realized rust resistance was found. Nevertheless, Figure $3 a$ and $b$ shows that realized I50s and S50s do not follow any clear age trend. The statistically significant differences in rust resistance among ages were probably because assessments of rust incidence at ages 12 and 16 are very difficult and masked by mortality, due to the failure to install permanent plots, making later measures less reliable. Additionally, realized I50 and S50 are always significantly smaller than $50 \%$ (which indicates more resistance than unimproved material), meaning a positive and stable assessment of realized gain across ages. Few studies have analyzed the effect of age on rust resistance in slash pine, and our results agree with the only reference showing that realized gains for rust resistance was not influenced by age (DHAKAL et al., 1996).

\section{Realized Gains in Growth and Stand Yield}

The analysis of growth and stand yield variables was conducted using data from the last measurement (approximately 16 years old) nearing rotation age. Realized gains in dominant height (SI25), tree volume (TREEVOL) and stand yield (MAI) were last evaluated in this same set of trials at 12 years, and projected gains from a growth model were estimated at rotation-age for volume (BRAWNER, 1998; BRAWNER et al., 1999). Goals of this analysis were to estimate actual gains in growth traits at the older age and to validate the previous growth model projections.

\section{Individual site analysis}

As mentioned previously, gains for growth and stand yield traits in this study were not thought to be due to genetic differences in growth rates, because the mean volume breeding values predicted for seedlots $R R$ (mixture of 6 rust-resistant families) and $R S$ (mixture of 6 rust-susceptible families) are nearly identical (13\% and $11 \%$, respectively). Therefore, any gain in growth detected should be attributed to the seedlots' differences in rust resistance. Examination of seedlot differences for growth variables in the site-by-site analysis at 16 years old evidenced very consistent, although not necessarily significant, results in the four high-rust-hazard ${ }^{6)}$ sites (trials 552, 553, 554, and 555). However, trial 551, the only trial growing on a moderate-rust-hazard site (Table 1), had an opposing trend (Table 2).

Realized gains for dominant height (SI25) were slightly positive (3\%) on the average of high-rust-hazard sites (Table 2c). These gains might have been positive

\footnotetext{
6) Low, moderate, and high rust hazard represents $<10 \%$, $10-30 \%$, and $>30 \%$ of rust incidence, respectively, according to SCHMIDT (1998).
} 
because on high-rust-hazard sites rust infection eventually reduced height growth in the $R S$ seedlot more than in the $R R$ seedlot. In contrast, slightly and non-significant negative gains $(-3.6 \%)$ in the moderate-rust-hazard site (trial 551) could have been produced because the lower infection would not be enough to express a difference on SI25 between seedlots.

Height-dbh ratio (HDR) was consistently higher for the $R R$ seedlot compared to the $R S$ seedlot across all trials (Table $2 d$ ), indicating less taper in the $R R$ seedlot. The nature of this index is highly influenced by other variables like stand density or height, and therefore, the differences could be due to genetic differences for these other variables.

In the case of individual tree volume (TREEVOL), differences between seedlots were not generally significant except in trial 551 (Table 2e). The significant and negative gain $(-19.3 \%)$ obtained in TREEVOL at trial 551 (moderate-rust-hazard) could be the effect of lower mortality in $R R(30 \%)$ than in $R S(42 \%)$ without a detrimental effect of rust on growth rate in the remaining trees. But it is unclear why this happened only in the moderate-rust-hazard site.

The gains in MAI (mean annual increment in $\mathrm{m}^{3} \mathrm{ha}^{-1}$ year ${ }^{-1}$ ), which represent gains in stand yield, were almost always large and positive in all sites (Table 2f), demonstrating higher stand yield for the $R R$ seedlot. The only slightly negative gain was obtained, again, in the moderate-rust-hazard site (trial 551, -2.8\%). In contrast, the high-rust-hazard sites averaged gains of $30.5 \%$ for the $R R$ seedlot. Further, gains were consistently positive in each combination of oak and culture treatments, including three of the four treatments in trial 551 (data not shown for the two culture and oak treatments). In trial 551, only the combination oak-free plus no-culture treatment had a negative gain $(-18.7 \%)$, which accounts for the small negative gain for the entire trial. This generally positive gain in MAI is likely due to the combined effects of rust susceptibility, which lead to higher mortality in the $R S$ compared to the $R R$ seedlot and slightly slower growth due to more stem galled trees in the $R S$ seedlots.

The impact of site, silviculture and age on realized gains for growth and stand yield

Across-sites analysis at each age. Results from the across-sites analysis are shown in Figure $3(d, e, f$, and $g$ ) and generally represent the average gains to be obtained when deploying rust-resistant seedlots on high-rust-hazard sites. The small, but highly significant realized gain, obtained for SI25 (2.5\%, Figure $3 d)$ is strong evidence of the effect of rust on height growth, given that the inherent genetic growth rates of the $R R$ and $R S$ seedlots are identical. Therefore, the gain obtained is probably due to lower growth rate for the $R S$ seedlot caused by more stem-galled trees, which has been found in other studies (ScHMIDT et al., 1981; BRAWNER, 1998; LOPEZ-UPTON et al., 2000).

No gains were found for individual tree volume (Figure 3f), most likely because individual volume of living trees was influenced by both mortality and reduced growth when rust infection was present. Rust associated mortality (Figure 3c) generated lower survival, and therefore, lower stand density on $R S$ plots, allowing remaining trees to growth faster in dbh than trees on $R S$ plots with higher stand density. Conversely, those trees with stem galls probably suffered reduced individual tree growth (ScHMidT et al., 1981; BRAWNER, 1998) and more of these stem-galled trees occurred in the $R S$ seedlot. As a result of this balance between faster and slower growth rate, realized gains for TREEVOL close to zero on high-rust-hazard sites seems reasonable. The fact that $R S$ trees grew faster in $\mathrm{dbh}$ and slower in height than $R R$ trees probably explains the $5.2 \%$ in HDR gain obtained in this study (Figure 3e).

Finally, stand yield, as represented by MAI, was the most important outcome of the differential rust resistance between seedlots. The highly significant gain in MAI $(24.7 \%$, Figure $3 g)$ is likely the result of two factors related to rust susceptibility. Stand yield loss is primarily associated with stem-galled trees that die and or grow more slowly throughout the rotation (SCHMIDT et al., 1981). In this study, both increased rust-associated mortality and reduced height growth are clear (Figure $3 c$ and $d$ ).

The $24.7 \%$ gain in MAI obtained in the BMP study for slash pine represents an absolute gain in stand yield of $32.9 \mathrm{~m}^{3} \mathrm{ha}^{-1}$ (inside-bark volume) at age 16 . This value can be conservatively extrapolated to 25-year-rotation age. At that age the absolute gain in stand yield would be $51.4 \mathrm{~m}^{3} \mathrm{ha}^{-1}$ (735 feet acre $^{-1}$ ) above a rust susceptible yield of about $205 \mathrm{~m}^{3} \mathrm{ha}^{-1}\left(2940\right.$ feet $^{3}$ acre $\left.^{-1}\right)$, without considering intensive silvicultural management. The $24.7 \%$ gain in MAI compares favorably with the $25 \%$ gain in stand yield projected to age 20 using growth models by BRAWNER et al. (1999) from 12-year-old data in the same study. Although the gains in this study compare rust-resistant and rust-susceptible seedlots and therefore, could over-estimate the genetic gains of rustresistant seedlots compared to unimproved material, our conservative extrapolation of gains to rotation age would ameliorate the effect. Additionally, the impact of these realized gains would be even more important considering the additional effect of rust resistance on wood quality and marketability (WEBB and PATTERSON, 1984; Anderson et al., 1986; Pye et al., 1997; CubBage et al., 2000). Realized gains for MAI varied substantially among sites (Table 2f) and between oak treatments (data not shown). The interactions, however, were never statistically significant $(\alpha=0.1)$ as confirmed by lack of significance of seedlot $\mathrm{x}$ site and seedlot $\mathrm{x}$ oak (Table 3 ). This absence of seedlot $\mathrm{x}$ environment interaction might not be true when analyzing single families, particularly in low-rust-hazard sites (KUHLMAN et al., 1995; DIETERS et al., 1996; SCHMIDT et al., 1999).

Predicted volume breeding values for $R S$ and $R R$ are $11 \%$ and $13 \%$, respectively. This difference of only $2 \%$ cannot account for the $24.7 \%$ realized gain obtained in MAI. WhITE et al. (1996) predicted yield indices that combine R50 and tree volume, putting more weight on R50 in high-rust-hazard stands. In order to use these indices, rust hazard for these five sites was categorized in low, moderate, and high-rust-hazard representing 
$<20 \%, 20-60 \%$, and $>60 \%$ of total rust incidence, respectively, on unimproved material at five years of age. Under this criterion, in general, the BMP trials are placed in moderate-rust-hazard sites where the yield index earned predicted gains in yield of $8 \%$ and $17 \%$ for $R S$ and $R R$, respectively. Furthermore, supposing highrust-hazard sites for the BMP study, predicted values would be $6 \%$ and $21 \%$ for $R S$ and $R R$, respectively. These predicted differences of $9 \%$ (moderate rust hazard) and $15 \%$ (high rust hazard) considerably underestimate the $24.7 \%$ gain of the $R R$ seedlot in this study. The devastating effects of rust infections on stand yield seem to be more serious than predicted at these rust hazard levels.

Age-seedlot interactions. The across-site analysis, using age as a repeated measure, demonstrated highly significant age $\mathrm{x}$ seedlot interactions for SI25 and HDR. The significance of those interactions for the variables TREEVOL and MAI was not available, because the algorithm used did not converge to a solution. Nevertheless, looking at the site-by-site analysis, age $\mathrm{x}$ seedlot interactions appeared to have little importance for TREEVOL and highly important meaning for MAI.

Figure $3 d$ illustrates the change of ranking for SI25. Although the negative gain at age 5 was not significant, it occurred consistently in four of five trials (Table 2c). Later, there were no differences in seedlots at age 12 , and at age 16 there were positive and significant gains of the $R R$ seedlot for SI25. This variable is not influenced directly by mortality (i.e. by density) (PIENAAR and Rheney, 1996; PIENAAR and ShIVER, 1984); hence, the age $\mathrm{x}$ seedlot interaction might be due to fast early height growth in the $R S$ seedlot followed by reduced growth rate after stem infection. Supporting this idea, evidence that rust susceptibility is related to higher availability of succulent tissue in the plants (SCHMIDT et $a l ., 1981)$ could mean that genotypes with a high initial growth rate are more susceptible to rust. However, this correlation between high initial growth rate and rust susceptibility has never been supported by progeny test analysis in slash pine.

The change of ranking for HDR (Figure 3e) had the same pattern as SI25, but this interaction was likely caused by mortality. Small differences in mortality at age 5 (Figure $3 c$ ) between seedlots allowed $R S$ to have similar diameters but larger heights than $R R$ generating higher HDR in $R S$ than in $R R$. Later at ages 12 and 16 , mortality and reduced height growth in the $R S$ seedlot changed the HDR by allowing a faster diameter growth rate than in $R R$ and therefore, positive gains.

In the case of MAI, the age $\mathrm{x}$ seedlot interactions had a scale effect, steadily increasing gain with age (Figure $3 g$ ). This pattern was very consistent among sites, and it was coincident with the pattern of mortality in the study (Figure 3c). The projected gains obtained by BRAWNER et al. (1999) for slash pine in the BMP study (25\% at age 20 and $33 \%$ at age 25) follows about the same tendency across time, but apparently that projection still underestimated the realized gains in stand yield. Following the tendency shown in Figure $3 g$, the $24.7 \%$ realized gain in MAI obtained at age 16 in this study, should be larger at age 20 than the $25 \%$ projected for BRAWNER et al. (1999).

\section{Conclusions}

Rust resistance was substantially improved in slash pine in this study by using a rust-resistant seedlot (mixture of 6 rust-resistant families) on high-rust-hazard sites. The results were consistent across sites and silvicultural treatments with no seedlot $\mathrm{x}$ environment interaction, supporting the idea of stability of genetic rust resistance across different environments, at least when using seedlot mixtures with several families. Additionally, assessments of rust resistance were consistent across ages with small changes in the observed realized gains. The consistently lower total rust incidence in the $R R$ seedlot (realized I50 $=21.9 \%$ ) is smaller than the expectation (mean predicted $\mathrm{R} 50=31.4 \%$ ), although there is an agreement among realized and predicted values for substantial and positive gains.

Realized rust resistance in slash pine had a positive, but small, effect on dominant height (SI25) and the height-dbh ratio (HDR), but no effect on individual tree volume (TREEVOL). Nevertheless, it had a significant and positive effect on stand yield (MAI). At age 16, the realized gain in stand yield was approximately $25 \%$, consistent across sites and silvicultural treatments. If this realized gain is extrapolated conservatively to a 25year-rotation age, the realized gain in stand yield (inside-bark volume) obtained by planting rust resistant material in high-rust-hazard sites would be at least $51.4 \mathrm{~m}^{3} \mathrm{ha}^{-1}$ (735 feet ${ }^{3}$ acre $^{-1}$ ) above a rust susceptible yield of about $205 \mathrm{~m}^{3} \mathrm{ha}^{-1}$ (2940 feet acre $^{-1}$ ). Realized gain in stand yield was primarily influenced by rustassociated mortality and slower individual tree height growth in the rust susceptible seedlot. This amount of realized gain reflects a larger impact of rust resistance in stand yield than projected by growth models or predicted by yield indices in high-rust-hazard sites. The devastating effects of rust infection on stand yield, and possibly on wood quality and marketability, are clearly overcome by genetic rust resistance.

Realized gains for growth and stand yield traits varied across ages. The accumulated effect of rust infection across age generated increasing gains in dominant height, height-dbh ratio, and stand yield from age 5 to age 16 , indicating that assessing realized gains for these traits must be done near rotation age. In particular, differences of realized gains in stand yield were large across ages, coinciding with the pattern of mortality due to rust infection. The assessing of age-age correlations in order to predict gains in stand yield due to rust resistant seedlots will be an important challenge when this study reaches the rotation age in five or 10 more years.

\section{Acknowledgments}

The authors would like to acknowledge the Integrated Forest Pest Management Cooperative (IFPM) that provided the information about the trials, the Cooperative Forest Genetics Research Program (CFGRP) that sponsored this research, and all the CFGRP members who made the 
data collection possible. Also, we would like to thank GREG POwELL for his help with the preparation of fieldwork and data management, and to graduate students Maheteme Gebremedhin, Veronica Emhart, Salvador GEZAN, and BRIAN BALTUNIS for their invaluable help in the field. This research was partially supported by the Florida Agricultural Experiment Station.

\section{References}

Anderson, R. L., J. P. McClure, N. Cost and R. J. Uhler (1986): Estimating fusiform rust losses in five southeast states. South. J. Appl. For. 10: 237-240.

BAILEY, R. L. and J. R. BRooks (1994): Determining site index and estimating timber volumes without measuring heights. South. J. Appl. For. 18: 15-18.

BANKs, B. D., I. L. MAO and J. P. WALter (1985): Robustness of the restricted maximum likelihood estimator derived under normality as applied to data with skewed distribution. J. Dairy Sci. 68: 1785-1792.

BozIVICH, H., T. A. BANCROFT and H. O. HARTlEy (1956): Power of analysis of variance test procedures for certain incompletely specified models, I. Ann. Math. Statist. 27: 1017-1043.

Brawner, J. T. (1998): Gains in survival, rust incidence, volume, and economic value from rust resistant slash and loblolly pine. Thesis (M.S.). Sch. of Forest Resour. and Conserv. Univ. of Florida. Gainesville, FL. 76 pp.

Brawner, J. T., D. R. Carter, D. A. Huber and T. L. White (1999): Projected gains in rotation-age volume and value from fusiform rust resistant slash and loblolly pines. Can. J. For. Res. 29: 737-742.

CRitchfield, W. B. and E. LitTle JR. (1966): Geographic distribution of the pines of the world. Forest Serv., U.S. Dept. Agric., Washington D.C. Misc. Publ. 991. 97 pp.

Cubbage, F. W., J. M. Pye, T. P. Holmes and J. E. WAGNER (2000): An economic evaluation of fusiform rust protection research. South. J. Appl. For. 24: 77-85.

DHAKAL, L. P. (1995): Realized genetic gains and validation of breeding values for slash pine. Thesis (M.S.). Sch. of Forest Resour. and Conserv. Univ. of Florida. Gainesville, FL. 56 pp.

Dhakal, L. P., T. L. White and G. R. Hodge (1996): Realized genetic gains from slash pine tree improvement. Silvae Genet. 45: 190-197.

Dieters, M. J., G. R. Hodge and T. L. White (1996): Genetic parameter estimates for resistance to rust (Cronartium quercuum) infection from full-sib tests of slash pine (Pinus elliottii), modelled as functions of rust incidence. Silvae Genet. 45: 235-242.

EldRIDGe, K., J. DAVISON, C. HARWOOD and G. VAN WYK (1994): Eucalypt domestication and breeding. Oxford Sci. Publi. Oxford Univ. Press. New York. 288 pp.

EL-KASSABY, Y. A., D. RUdiN and R. YAZDANI (1989): Levels of outcrossing and contamination in two Pinus sylvestris L. seed orchards in northern Sweden. Scand. J. For. Res. 4: 41-49.

FAnG, Z., B. Borders and R. BAILey (1999): Tree volume and upper-stem diameter predictions for planted loblolly and slash pine based on a compatible volume-taper system with segmented-stem form factors. Plant. Manage. Res. Coop. Warnell Sch. of Forest Resour. Univ. of Georgia. PMRC Tech. Rep. No. 1999-3. 20 pp.

Foster, G. S. (1992): Estimating yield: Beyond breeding values. In: Handbook of quantitative forest genetics, eds. L. Fins, S. T. FriEdman and J. BRotschol. Kluwer Acad. Pub., Boston MA. 236 pp.
Friedman, S. T. and W. T. AdAMs (1985): Estimation of gene flow into two seed orchards of loblolly pine (Pinus taeda L.). Theor. Appl. Genet. 69: 609-615.

GoDDARD, R. E. and R. A. SCHMidT (1979): Relative geographic stability of resistance to fusiform rust of selected slash pine families. In: Proc. $15^{\text {th }}$ South. For. Tree Improv. Conf. Mississippi State, MS. pp. 99-107.

GRIGGS, M. M. and R. A. Schmidt (1977): Increase and spread of fusiform rust. In: R. J. DinUs and R. A. SCHMidT, eds. Management of fusiform rust in southern pines. Symp. Proc. Univ. Fla., Gainesville, FL. pp. 32-38.

Hodge, G. R., R. A. Schmidt and T. L. White (1990): Substantial realized gains from mass selection of fusiform rust-free trees in highly infected stands of slash pine. South. J. Appl. For. 14: 143-146.

Hodge, G. R., T. L. White, G. L. Powell and S. M. De SouzA (1989): Predicted genetic gains from one generation of slash pine improvement. South. J. Appl. For. 13: 51-55.

Hodge, G. R., T. L. White, R. A. Schmidt and J. E. Allen (1993): Stability of rust infection ratios for resistant and susceptible slash and loblolly pine across rust hazard levels. South. J. Appl. For. 17: 188-192.

Kuhlman, E. G., H. R. Powers and W. D. Pepper (1995): Relative fusiform rust resistance of loblolly and slash pine sources and families in Georgia and South Carolina. South. Res. Stn. Forest Serv. Asheville, NC. Res. Pap. SE-291. 12 pp.

Lambeth, C., M. Endo and J. Wrigth (1994): Genetic analysis of 16 clonal trials of Eucalyptus grandis and comparisons with seedling checks. Forest Sci. 40: 397-411.

Lopez-Upton, J., T. L. White and D. A. Huber (1999): Effects of site and intensive culture on family differences in early growth and rust incidence of loblolly and slash pine. Silvae Genet. 48: 284-293.

Lopez-Upton, J., T. L. White and D. A. Huber (2000): Species differences in early growth and rust incidence of loblolly and slash pine. Forest Ecol. and Manage. 132: $211-222$.

LowERTS, G. A. (1986): Realized genetic gain from loblolly and slash pine first generation seed orchards. In: IUFRO symp. on breeding theory, progeny testing, and seed orchards. Williamsburg, VA. pp. 361-372.

McKeand, S. E., H. V. Amerson, B. Li and T. J. Mullin (2003): Families of loblolly pine that are the most stable for resistance to fusiform rust are the least predictable. Can. J. For. Res. 33: 1335-1339.

Phelps, W. R. and C. W. Chellman (1975): Impact of fusiform rust in North Florida slash pine plantations. Plant Dis. Rep. 59: 481-485.

PienaAR, L. V., H. H. PAGE and J. W. Rheney (1990): Yield prediction for mechanically prepared slash pine plantations. South. J. Appl. For. 14: 104-109.

PienaAR, L. V. and J. W. Rheney (1996): Results of a slash pine spacing and thinning study in the southeastern coastal plain. South. J. Appl. For. 20: 94-98.

PienaAR, L. V. and B. D. SHIVER (1984): The effect of planting density on dominant height in unthinned slash pine plantations. Forest Sci. 30: 1059-1066.

Pye, J. M., J. E. Wagner, T. P. Holmes and F. W. Cubbage (1997): Positive returns from investment in fusiform rust research. South. Res. Stn. Forest Serv. Asheville, NC. Res. Pap. SRS-4. 55 pp.

SAS Institute INC. (1990): SAS/STAT ${ }^{\circledR}$ user's guide, version $6,4^{\text {th }}$ Ed. Vol. 2. SAS ${ }^{\circledR}$ Institute Inc. Cary, NC. $846 \mathrm{pp}$. 
SAS Institute INC. (1996): SAS $^{\circledR}$ system for mixed models. SAS ${ }^{\circledR}$ Institute Inc. Cary, NC. 633 pp.

SATTERTHWAite, F. E. (1946): An approximate distribution of estimates of variance components. Biometrics Bull. 2: 110-112.

SCHMIDT, R. A. (1998): Fusiform rust disease of southern pines: biology, ecology and management. Agric. Exp. Stn. Inst. Food and Agric. Sci. Univ. of Florida. Gainesville, FL Tech. Bull. 903. 14 pp.

SCHMidT, R. A. and J. E. Allen (1997): Fusiform rust epidemics in family mixtures of susceptible and resistant slash and loblolly pines. In: Proc. 24th South. For. Tree Improv. Conf. Orlando, FL. pp. 309-319.

Schmidt, R. A., J. E. Allen, R. P. Belanger and T. Miller (1995): Influence of oak control and pine growth on fusiform rust in young slash and loblolly pine plantations. South. J. Appl. For. 19: 151-156.

Schmidt, R. A., D. S. Duncan and J. E. Allen (1999): Stability of fusiform rust resistance slash pine families among years and locations in the southeastern costal plain. Forest Biology Research Cooperative Report No 6. Univ. of Florida, Gainesville, FL. 31 pp.

Schmidt, R. A. and R. E. GodDARD (1971): Preliminary results of fusiform rust resistance from field tests of selected slash pines. In: Proc. 11 ${ }^{\text {th }}$ South. For. Tree Improv. Conf. Atlanta, GA. pp. 37-44.

Schmidt, R. A., H. R. Powers JR. and G. A. Snow (1981): Application of genetic disease resistance for the control of fusiform rust in intensively managed southern pine. Phytopathology 71: 993-997.

SoHn, S. and R. E. GoDDARD (1979): Influence of infection percent on improvement of fusiform rust resistance in slash pine. Silvae Genet. 28: 173-180.

VERGARA, R. (2003): Estimation of realized genetic gains and validation of predicted breeding values using field trials with large rectangular plots of slash pine (Pinus elliottii var. elliottii). Thesis (M.S.). Sch. of Forest Resour. and Conserv. Univ. of Florida. Gainesville, FL. 98 pp.

Walkinshaw, C. H. (1999): Promising resistance to fusiform rust from southeastern slash pines. South. Res. Stn. Forest Serv. Asheville, NC. Rep. FSRP-SRS16. $14 \mathrm{pp}$.

WebB, R. S. and H. D. PATTERSON (1984): Effect of stem location of fusiform rust symptoms on volume yields of loblolly and slash pine sawtimber. Phytopathology 74: 980-983.

WestFall, P. H. (1987): A comparison of variance components estimates of arbitrary underlying distributions. J. Amer. Stat. Asoc. 82: 866-873.

White, T. L. (1987): A conceptual framework for tree improvement programs. New Forests 4: 325-342.

WHITE, T. L. and G. R. HodGE (1988): Best linear prediction of breeding values in forest tree improvement. Theor. Appl. Genet. 76: 717-719.

White, T. L., G. R. Hodge and G. L. Powell (1993): An advanced generation tree improvement plan for slash pine in the southeastern United States. Silvae Genet. 42: 359-371.

White, T. L., G. L. Powell and G. R. Hodge (1996): Genetics of slash pine: Parameter estimates and breeding value predictions. Confidential report. Coop. Forest Genet. Res. Prog., Sch. of Forest Resour. and Conserv. Univ. of Florida, Gainesville, FL. 166 pp.

Williams, E. R. and A. C. Matheson (1994): Experimental design and analysis for use in tree improvement. CSIRO, ACIAR. East Melbourne, Aust. 174 pp.

ZoBel, B. and J. TALBERT (1984): Applied forest tree improvement. John Wiley and Sons, Inc., New York. 505 pp.

\title{
Age-related Trends in Genetic Parameters for Jack Pine and Their Implications for Early Selection
}

\author{
By Y. H. WenG ${ }^{1), *}$, K. J. Tosh ${ }^{1)}$, Y. S. PARK ${ }^{2)}$ and M. S. Fullarton ${ }^{1)}$
}

(Received 20 th June 2006)

\begin{abstract}
Trends in genetic parameters for height growth of jack pine (Pinus banksiana Lamb.) were examined over three series of family tests throughout New Brunswick. Data were analyzed for each site and across sites within each series. Although individual narrow sense heritability estimates from single-site analyses varied substantially

\footnotetext{
1) New Brunswick Department of Natural Resources, Kingsclear Forest Nursery, Island View, NB, Canada, E3E 1G3.

$\left.{ }^{2}\right)$ Natural Resources Canada, Canadian Forest Service-Atlantic Forestry Centre, P.O. Box 4000, Fredericton, N.B. Canada, E3B 5P7.

*) Corresponding author: Telephone 506-444-5125, Fax 506-4444917. E-mail: $\underline{\text { Yuhui.Weng@@gnb.ca. }}$
}

from site to site and showed no consistent age-related pattern, the estimates from across-site analyses showed an increasing trend to age 20. Similar as individual narrow sense heritability, the coefficient of additive genetic variance estimated from single site showed more variation than those estimated from across site analyses. Age-age (type-a) genetic correlations for height were high and could be well predicted by a $L A R^{2}$ model, where $L A R$ is the natural logarithm of the ratio between two ages at assessment. Type-b genetic correlations were high and of similar magnitude at different ages. Genetic correlations between height at different ages and volume at one-half rotation age were generally high. Taking the volume at one-half rotation age as the target trait, the selection for target trait from early selection at 